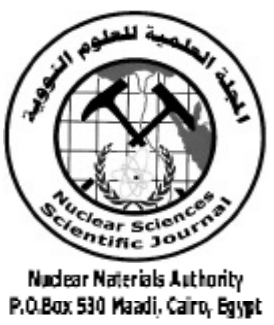

ISSN 2314-5609

Nuclear Sciences Scientific Journal

vol. 3, p $67-83$

2014

\title{
PETROLOGY AND RADIOACTIVITY OF GABAL AL - AGLAB YOUNGER GRANITE, CENTRAL EASTERN DESERT, EGYPT
}

\author{
AHMED A. ABU STEET; ABDEL ALIM A. ABU DIAB and SAMEH Z. TAWFIK \\ Nucleur Materials Authority, Cairo Egypt
}

\begin{abstract}
This study deals with petrology and radioactivity of Gabal Al-Aglab younger granite, central Eastern desert, Egypt. Geologically the area consists of ophiolotic Mélange and younger granite. The study reveals that the younger granite are post orogenic granites, characterized by high differential index, which in turn represents the latest stage of the successive younger granite intrusions. Microscopically, Gabal Al- Aglab younger granites is holocrystalline, medium to coarse grained, characterized by the predominance of perthite over plagioclase, quartz and biotite. Zircon, apatite, titanite, allanite, and opaque minerals are the accessory and secondary minerals. The pegmatites occur as lenticular and circular pockets at the periphery of the younger granites. Geochemically, the younger granites show mainly peraluminous to metaluminous character and originated from subalkaline magma in within plate tectonic setting (crustal thickness $>30$ $\mathrm{km}$ ) at water vapour pressure varying from 0.5 to $3 \mathrm{~kb}$ with crystallization temperature between $670^{\circ}$ to $800^{\circ}$ C. Field survey together with the complied total count aeroradiometric map reveal that the pegmatites of Gabal Al- Aglab younger granite is significantly highly radioactive compared to the surrounding rocks. The uranium content varies between 3 to $12 \mathrm{ppm}$ with an average of $7.1 \mathrm{ppm}$ and thorium from 11 to $35 \mathrm{ppm}$ with an average of $20 \mathrm{ppm}$ and an average ratio $(\mathrm{Th} / \mathrm{U}) 2.8$. The pegmatites show higher $\mathrm{U}$ contents relative to their hosted younger granites as identified by microscopic investigation, scanning electron microscopy and confirmed by XRD.
\end{abstract}

\section{INTRODUCTION}

The studied area represents a part of the Red sea Hills of the Eastern Desert of Egypt. It is covered by moderate to high elevated terrains of rugged topography. The topographic features of the area are mainly controlled by the structural elements and the lithologic characteristics of each rock type. Gabal Al- Aglab (about $87 \mathrm{~km} 2$ ) is located between lat. $27^{\circ} 12^{\prime}$ and $27^{\circ} \quad 20^{\prime} \mathrm{N}$ and long. $33^{\circ} 00^{\prime}-33^{\circ} 05^{\prime} \mathrm{E}$ (Fig 1). The exposed basement rocks are ophiolitic mélange and younger granites.

Vein type uranium mineralization of Precambrian age structurally controlled, for example Gabal El-Missikat, Gabal El- Erediya and Gabal Qatter in the Central and Northern Eastern Desert (Bakhit, 1978; Hussein et al., 1986; Bakhit and Meleik, 1990; Hussein and Sayyah, 1991; Roz, 1994; Shalaby, 1995 and Moharem, 1997 and 1999). Detailed studies showed that the highly radioactive bodies display great similarities in their type of mineralization, host rocks, country rocks and structures.The general geology, structure and radioactivity were discussed in previous works by El-Shazly et al. (1981), Bakhit (1989 and1992), El-Tahir (1985), Abdel Monem et al (1990) and Bakhit and El-Kassas (1992). The transfer of uranium from the more refractory minerals to uraninite during deuteric alterations are critical step which not only increase 


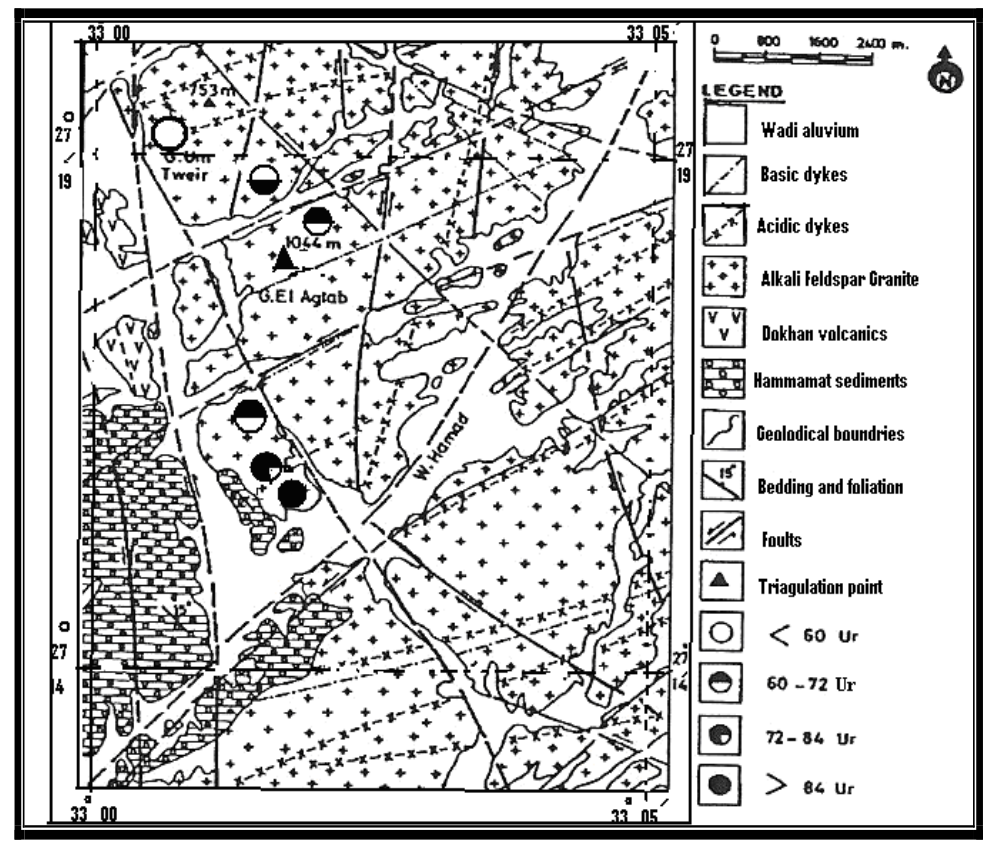

Fig. 1: Geological Map of Gabal Al- Aglab area (Modified after Ayoub, 2003)

the uranium content in the altered rocks, but also makes the uranium more readily leachable by late hydrothermal solutions (Cuney, 1978).

The Neoproterozoic crustal evolution of the Arabian-Nubian Shield was dominated by subduction-related processes. The evolution of the Shield, as summarized by stern (1993) and Kroner (1993) began some $950 \mathrm{Ma}$ ago with rifting followed by sea-floor spreading. A group of juvenile island arcs terranes were formed between 900-650 $\mathrm{Ma}$ at the initiation of subduction. The various terranes were welded together along ophiolite - bearing suture zones (microplate accretion ;Stoesser and Camp, 1985) followed by large - scale, calc alkaline magmatism, continental collision and accretion to the East Saharan Craton (Schandelmeier et al., 1987). Granitoid rocks constitute about half of the Egyptian basement complex. They have been differentiated into two broad categories, namely older and younger granitoids, based upon their composition and age relationships (ElRamly, 1972). The older granitoids are compositionally extended, ranging from quartz diorite to granite (predominantly trondhjemite, tonalite and granodiorite). They were emplaced during the main orogenic stage between 800 and 614Ma (Stern and Hedge, 1985; Hassan and Hashad, 1990). The younger granitoids are predominantly red to pink granites (monzogranite, syenogranite and alkali feldspar granite). They were emplaced in three phases (Greenberg, 1981) during the post-orogenic stage between 610 and $550 \mathrm{Ma}$ (Beyth et al., 1994 and Moghazi et al., 1998). The area under consideration was previously studied by El Amin and Alfy (1990) and Rashid (1998).

The objectives of this work is to use the petrological and whole rock geochemical data to reveal the nature of the processes involved in the generation of the younger granitoids of gabal Al-Aglab, as well as their tectonic setting and its ability to host uranium. 


\section{GEOLOGIC SETTING}

Three lithostratigraphic units have been recognized in the study area and the neighboring regions. 1) Hamamat sediments, 2) Dokhan volcanics and 3) younger granites. The younger granites are by far the most abundant and widely distributed rock unit.

Gabal Al-Aglab is an elliptic pluton intruding all the above mentioned rocks with the development of sharp contacts. It is predominantly pale pink to red, massive, elongated in the NW$\mathrm{SE}$ direction. The granite is dissected by dykes and veins of aplites, porphyries, pegmatite and jasper as well as felsite and basaltic dykes. It is bounded from the north and south by two NESW sinistral strike slip faults, and cut by several other faults and fractures.

Gabal Al-Aglab has experienced multiple deformation that caused by complex tectonic movements during the Pan African orogeny. Jasper is developed as fracture fillings associated with hematitization. The granite around the jasper veins is highly silicified showing deep reddish color due to the impregnation of feldspars by hematite dust. The fresh granite of G. AlAglab is medium to coarse grained. A deep reddish brown color characterizes the strongly ferruginated (hematitized) granite, while the lighter tones such as pinkish creamy color characterizes the kaolinized type and a lighter rosy tones for the silicified ones.

The outcrops of the stained granites of the shear zone in the central parts of Gabal AlAglab are mostly taking a linear northeastward trend, they are vertical to very steeply dipping southeast ( $\mathrm{N} 50^{\circ}$ to $55^{\circ} \mathrm{E}$, dipping $75-85 \mathrm{SE}$ ) . Besides, the well displayed alteration zone, there are red hematitization black manganese and iron oxide staining the shear zone. Hematitization is closely connected to the parts around the mineralization. In this location, the jasperoid vein is thin and varies from 2 to $5 \mathrm{~cm}$ in thickness.

\section{PETROGRAPHY}

In the present study, five thin sections were selected for modal analyses (Table 1) and were plotted according to the QAP diagram of Streckeisen (1976). The studied granitoids plot in the field of alkali feldspar granite (Fig.2).

Table 1: Modal mineralogical composition of Gabal Al-Aglab younger granite

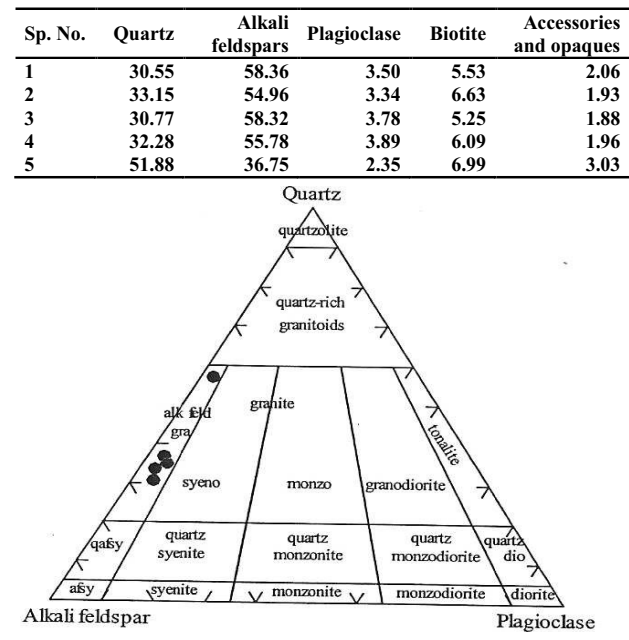

Fig. 2: Q-A-B Model ternary diagram (According to Streckeisen, 1976)

Microscopically, the younger granite is polycrystalline, medium to coarse - grained, characterized by the predominance of alkali feldspars over plagioclase feldspar, quartz and biotite. Zircon, allanite, apatite, titanite and opaque minerals are the accessory minerals.

The presence of two feldspars (perthite and plagioclase) suggests that the granite is mostly subsolvus and crystallized under high water pressure (Greenberg, 1981).

\section{The Alkali Feldspars}

They are represented by orthoclase and microcline perthites. Poikilitic plagioclase inclusions in alkali feldspars are common in some large quartz crystals. They occur as subhedral prismatic crystals showing simple twinning. The perthites are generally of the strings and patchy type (Fig.3). Perthites are engulfed by quartz and plagioclase, slightly kaolinized and sericitized (which may represent an old phase of perthite). 


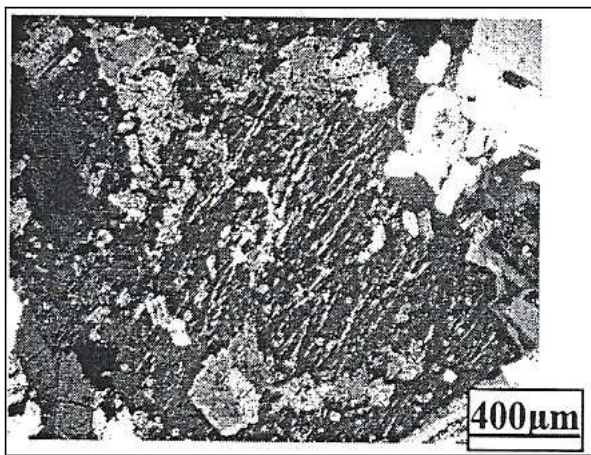

Fig.3: Strings and patchy types orthoclase perthite

\section{Quartz}

It occurs as medium to coarse subhedral to anhedral crystals. Occasionally, it occurs as inclusions of variable sizes and shapes within perthites and other minerals (Fig.4). The undeformed quartz crystals in minerals are probably the result of an early crystallization phase.

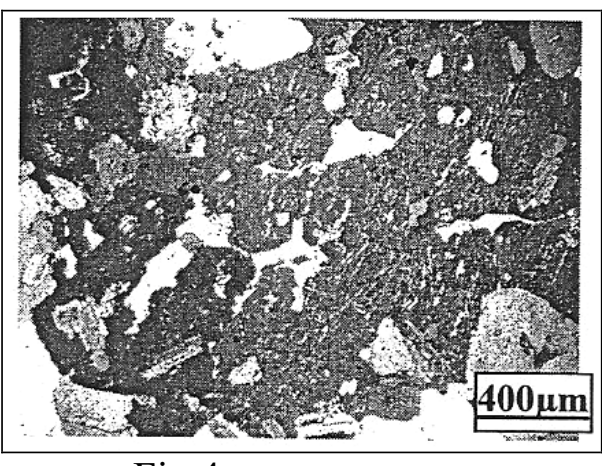

Fig.4: Orthoclase perthite engulfing skeletal quartz

\section{Plagioclase (An ${ }_{0-15}$ )}

It occurs as short prismatic zoned anhedral to subhedral crystals. Megacrysts of platy microcline perthite usually include prismatic albite crystals. Slightly altered small euhedral albite crystals are present. Plagioclase crystals are slightly kaolinized, in some instance their cores are more altered than the outer rims. Some plagioclase crystals are engulfed poikilitically in quartz and perthite.

\section{Biotite}

It forms medium to large irregular flakes resorbed by quartz and feldspars. It occurs as brown to reddish subhedral flakes. Some flakes show greenish color (chloritization) along their cleavage planes during alteration processes. Several biotite flakes exhibit dark pleochroic haloes (Fig 5). The biotite encloses zircon, apatite and iron oxides.

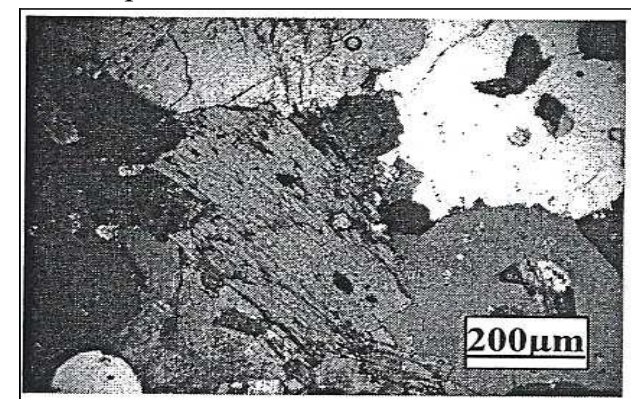

Fig 5: Pleochroic halo of zircon enclosed in biotite

\section{Allanite}

It occurs as euhedral prismatic zoned crystals associated with biotite (Fig 6) and titanite.

\section{Titanite}

It occurs as elongated and spheroidal subhedral crystals.

\section{Zircon}

It occurs either as minute euhedral to subhedral prismatic crystals (Fig 7) or as inclusions in quartz and biotite (Fig 8).

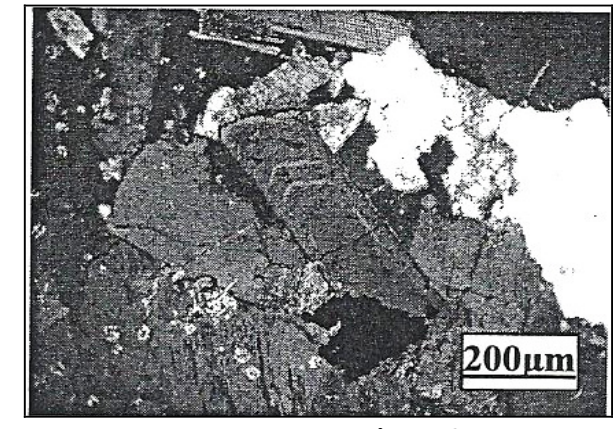

Fig.6: Zoned allanite crystal 


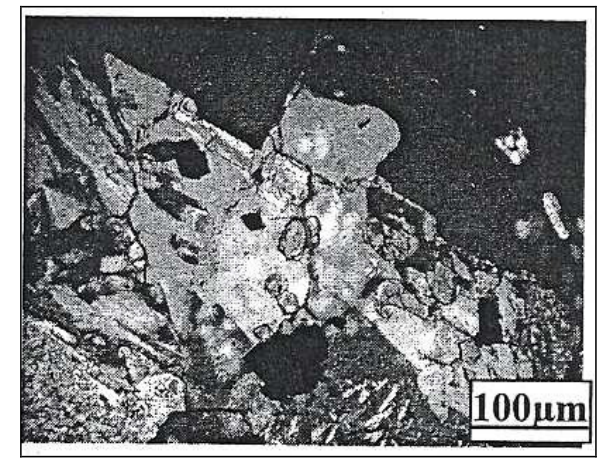

Fig.7: Zircon crystal included in quartz

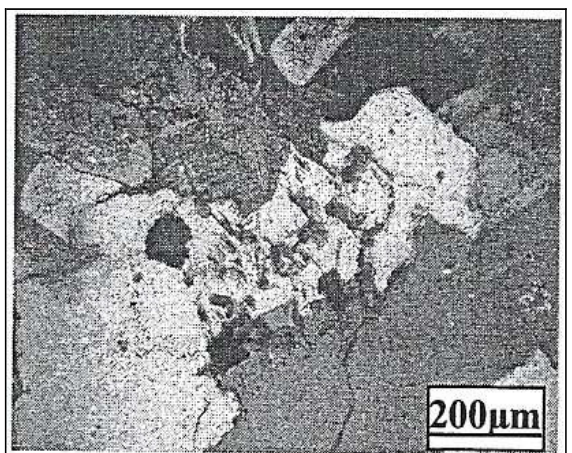

Fig.8: Fine crystals of apatite included in quartz.

\section{Epidote}

It is found as small greenish yellow to faint green crystals. Its cracks and cleavage planes are commonly filled with iron oxides. It is formed secondary as fracture filling associated with secondary muscovite or due to the alteration of feldspars.

\section{Sphene}

It is found as acicular to irregular crystals, usually associated with chloritized biotite and kaolinized feldspars. It is corroded by quartz, biotite and feldspars.

\section{Iron oxides}

They are found as small irregular patches in clusters or scattered in the rock. They are also found as tiny inclusions in mica, sphene, quartz and feldspars.

\section{GEOCHEMISTRY}

Ten representative samples are collected from the studied granitic masses. These samples are analyzed for major oxides and trace elements using the XRF techniques in the Laboratories of the Nuclear Materials Authority, Egypt. The analytical results are presented in Table (2).

Table 2: Major oxides (wt $\%$ ), trace elements (ppm), CIPW-norm and geochemical ratios of the studied younger granite of Gabal Al -Aglab

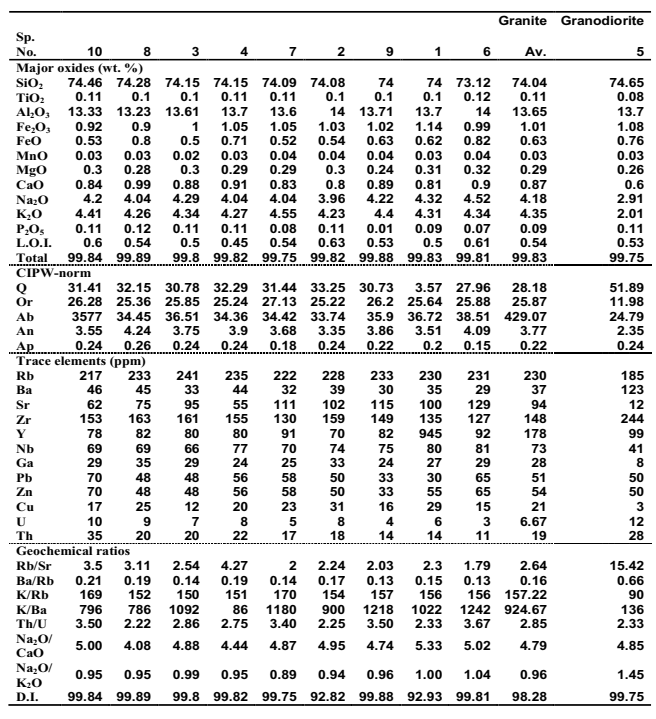

\section{Major and Trace Element Variations}

The studied granitoids have restricted range of $\mathrm{SiO}_{2}(74-74.65 \%)$. On the AlkaliSilica diagram (Fig.9) of Middlemost (1985) it is clear that most of the analyzed samples are plotted in the granitic field. Based on the $\mathrm{Na}_{2} \mathrm{O} / \mathrm{K}_{2} \mathrm{O}$ ratio (Table 2) the studied granitoids are clearly separated into two suites.

The granite suite is characterized by a $\mathrm{Na}_{2} \mathrm{O} / \mathrm{K}_{2} \mathrm{O}$ less than one and is enriched in $\mathrm{Rb}$ and $\mathrm{Sr}$ and depleted in $\mathrm{Ba}$ and $\mathrm{Zr}$. The granodiorite suite has a $\mathrm{Na}_{2} \mathrm{O} / \mathrm{K}_{2} \mathrm{O}$ ratio more than one and is enriched in $\mathrm{Ba}$ and $\mathrm{Zr}$ but depleted in $\mathrm{Rb}$ and Sr Table (2). The trends in the two granitoids suites are indistinguishable for the major components $\mathrm{Al}_{2} \mathrm{O}_{3}, \mathrm{MgO}$ and $\mathrm{CaO}$. In 
contrast, the plots of the trace elements $\mathrm{Sr}, \mathrm{Rb}$, $\mathrm{Nb}$ and $\mathrm{Y}$ show distinctly two different trends for the two suites.

To study the behavior of trace elements in the studied granite a chondrite - normalized pattern is given on Fig.10. It is seen that Al-Aglab granite is characterized by positive values of $\mathrm{Y}, \mathrm{Zr}, \mathrm{Nb}, \mathrm{U}$ and $\mathrm{Th}$ versus negative content of $\mathrm{Ba}, \mathrm{Sr}$, and $\mathrm{Ti}$. This reflects the role of feldspar and titanomagnetite in fractionation.

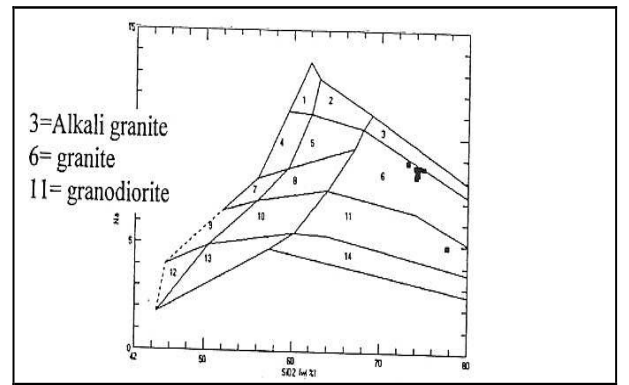

Fig. 9: Alkali-Silica diagram (According to Middlemost, 1985)

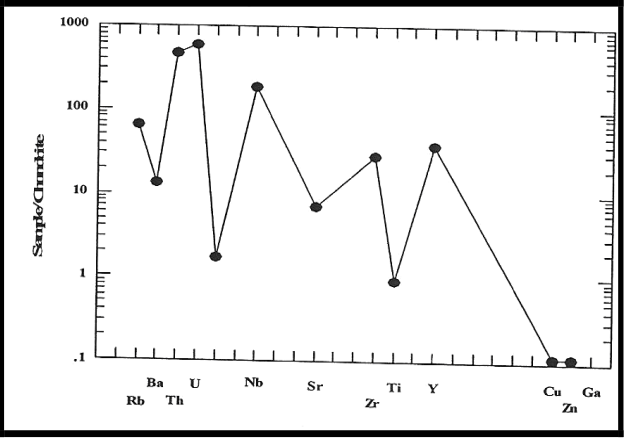

Fig.10: The Chondrite - normalized pattern of trace elements for Gabal Al Aglab younger granite

\section{$\mathrm{Rb}, \mathrm{Ba}$, and $\mathrm{Sr}$ Relationships}

Barium is a trace element in K-feldspar and biotite, where the potassium is the only major element of comparable ionic size to barium. The low magnitude of barium in the examined granite (av. $=38 \mathrm{ppm})$ suggests generation from crust dominated magma (Pearce et al. 1984) or from liquids affected by a greater extent of biotite fractionation (Dallagnoll et al. 1999). The size of strontium ion indicates that it can proxy for either calcium or potassium. Mason and Moore (1982) indicated that strontium in igneous rocks is present at most in plagioclase and $\mathrm{K}$ - feldspars.

Figure (11) shows a narrow range of $\mathrm{SiO}_{2}$ content from 73.12 to $74.65 \%$ in Al-Aglab granites. The silica content has a positive relation with $\mathrm{Ba}$ but negative relation with $\mathrm{Rb}$ and $\mathrm{Sr}$. Figure (12) shows a $\mathrm{Rb}-\mathrm{Sr}$ positive relation while a negative relation for $\mathrm{Ba}-\mathrm{Sr}$ and $\mathrm{Ba}-\mathrm{Rb}$.
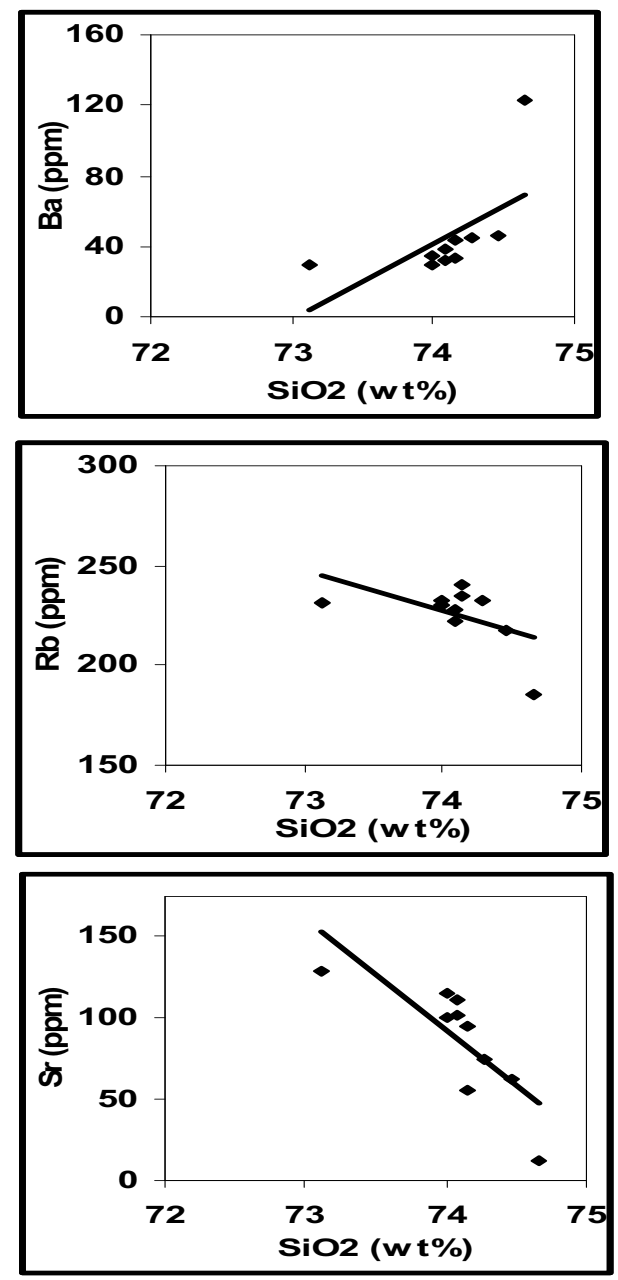

Fig.11: Variation diagram of $\mathrm{SiO}_{2}$ vs. $\mathrm{Ba}, \mathrm{Rb}$ and $\mathrm{Sr}$ 

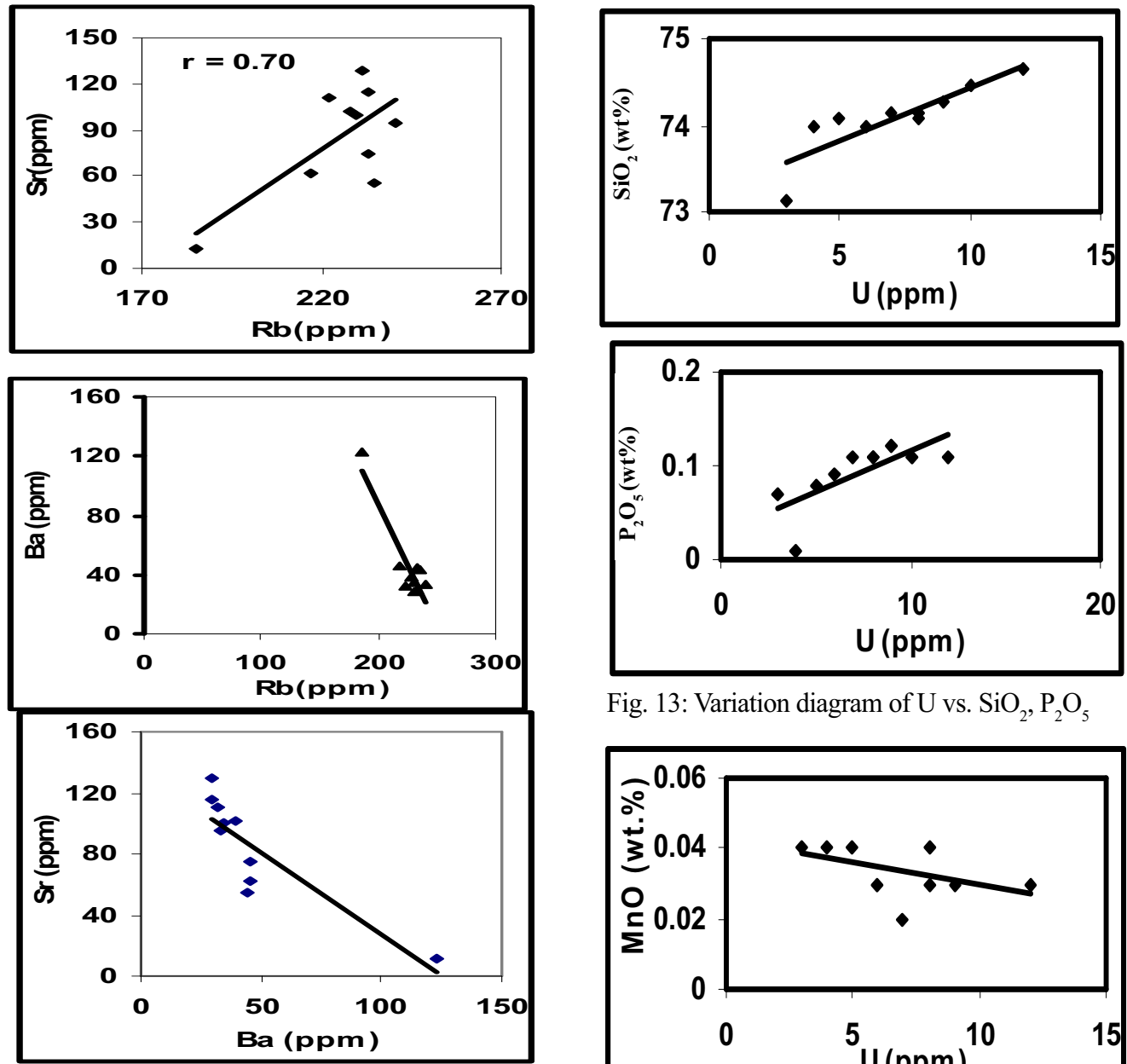

Fig. 13: Variation diagram of $\mathrm{U}$ vs. $\mathrm{SiO}_{2}, \mathrm{P}_{2} \mathrm{O}_{5}$

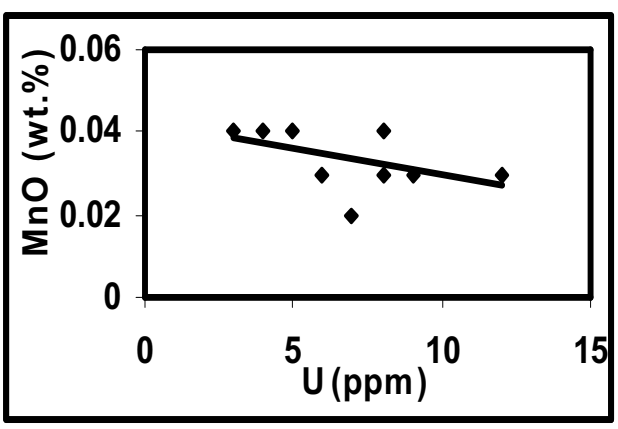

Fig.12: Binary diagrams of $\mathrm{Rb}$ vs. $\mathrm{Sr}, \mathrm{Ba}$ and $\mathrm{Ba}$ vs $\mathrm{Sr}$

Lehmann (1982) has regarded the $\mathrm{Rb} / \mathrm{Sr}$ ratio as a measure of the degree of magmatic differentiation, being higher with increasing differentiation.

Uranium Relations with Some Major and Trace Elements

Figure (13) shows a positive relation between $\mathrm{U}-\mathrm{SiO}_{2} \& \mathrm{U}-\mathrm{P}_{2} \mathrm{O}_{5}$, but Fig. $14 \mathrm{a} \& \mathrm{~b}$ shows a negative relation with $\mathrm{MnO}, \mathrm{Al}_{2} \mathrm{O} 3$, $\mathrm{K}_{2} \mathrm{O} \mathrm{TiO}_{2}$ and does not show a significant trends with $\mathrm{Fe}$ (total iron oxides) $\mathrm{MgO}, \mathrm{Na}_{2} \mathrm{O}$ and $\mathrm{CaO}$ (Fig.15)

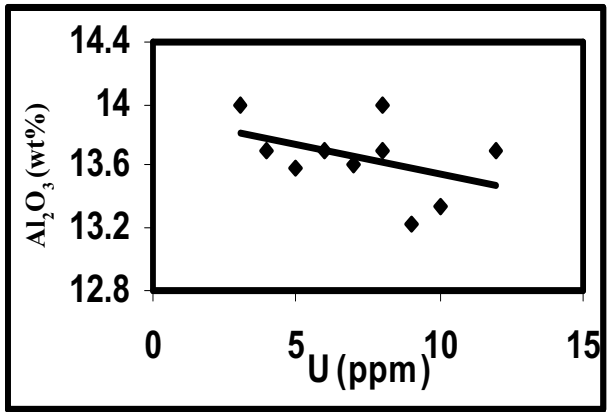

Fig. 14a: Variation diagram of $\mathrm{U}$ vs. $\mathrm{MnO}$ $\& \mathrm{Al}_{2} \mathrm{O}_{3}$ 

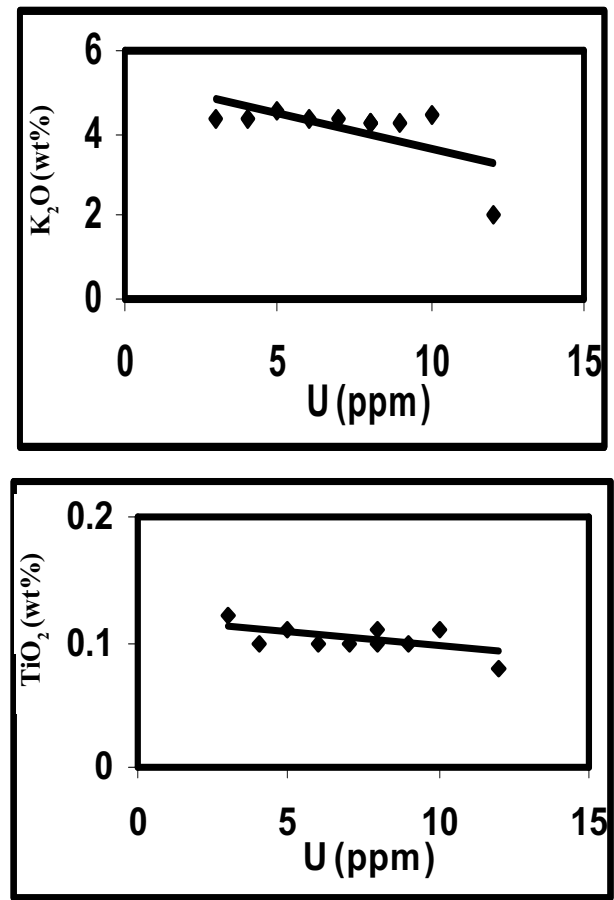

Fig.14b: Variation diagram of $\mathrm{U}$ vs. $\mathrm{K}_{2} \mathrm{O} \& \mathrm{TiO}_{2}$

Figure 16 shows a positive relation between $\mathrm{U}-\mathrm{Ba}, \mathrm{U}-\mathrm{Pb}$ and a negative relation between U - Rb, U-Sr (Fig.17). The above relations (Figs. 13-17) suggest that in all cases the studied granites are clustered in one group

\section{Magma Type and Tectonic Setting}

On the $\mathrm{Al}_{2} \mathrm{O}_{3} /\left(\mathrm{Na}_{2} \mathrm{O}+\mathrm{K}_{2} \mathrm{O}\right)$ versus $\mathrm{Al}_{2} \mathrm{O}_{3} /$ $\left(\mathrm{CaO}+\mathrm{Na}_{2} \mathrm{O}+\mathrm{K}_{2} \mathrm{O}\right)$ diagram of Maniar and Piccoli (1989) it is seen that the studied granitic samples are peraluminous to metaluminous ( Fig 18) . The conventional tectonic discrimination diagram $\mathrm{SiO}_{2}$ versus $\mathrm{Al}_{2} \mathrm{O}_{3}$ of Maniar and Piccoli (1989) shows that most of the samples (Fig.19) plot in the field of post orogenic granites (POG) except one sample (sample no. 5).

The geochemical data showed that the studied granite is rich in $\mathrm{Rb}$ and depleted in $\mathrm{Ba}$ and $\mathrm{Sr}$. The $\mathrm{K} / \mathrm{Ba}$ ratio (average $=995$ ) indicates an advanced magmatic differentiation
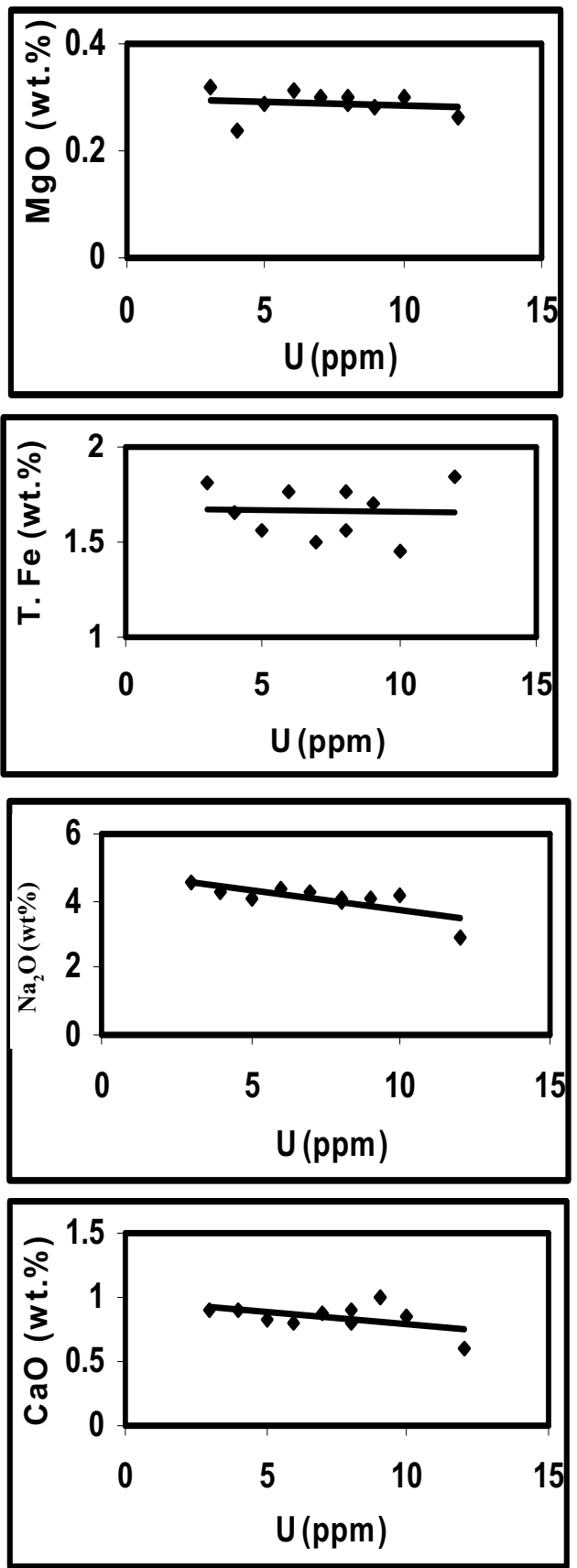

Fig. 15: Variation diagram of $\mathrm{U}$ vs. $\mathrm{MgO}$, T.Fe, $\mathrm{Na}_{2} \mathrm{O} \& \mathrm{CaO}$ 

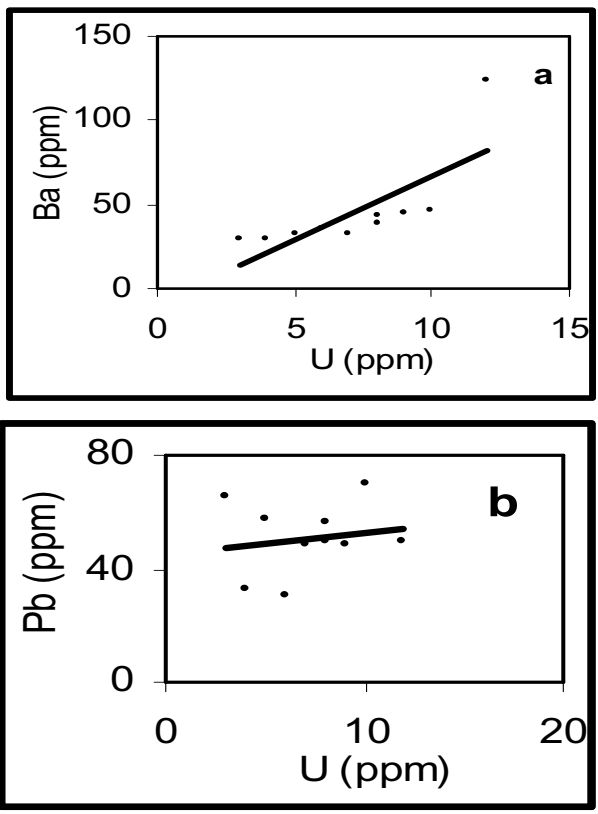

Fig. 16: Binary diagrams of $\mathrm{U}$ vs. $\mathrm{Ba} \& \mathrm{~Pb}$
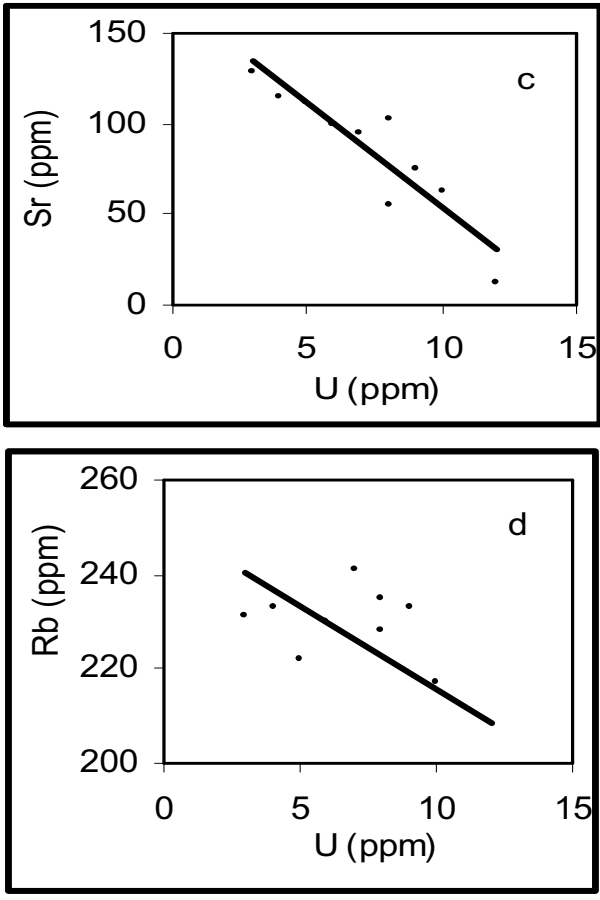

Fig.17: Binary diagrams of U vs. Sr \& Rb

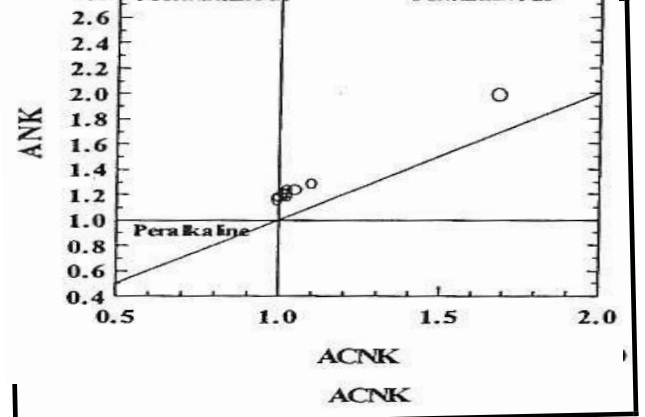

Fig.18 : (molar) $\mathrm{Al}_{2} \mathrm{O}_{3} /\left(\mathrm{Na}_{2} \mathrm{O}+\mathrm{K}_{2} \mathrm{O}\right)$ vs. $\mathrm{Al}_{2} \mathrm{O}_{3} /\left(\mathrm{CaO}+\mathrm{Na}_{2} \mathrm{O}+\mathrm{K}_{2} \mathrm{O}\right)$

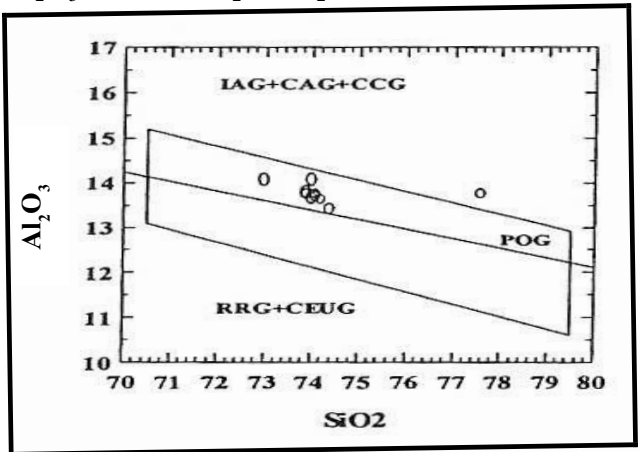

Fig.19: $\mathrm{SiO}_{2}$ vs. $\mathrm{Al}_{2} \mathrm{O}_{3}$ diagram, According to Maniar and Piccoli (1989).

where the low magnitude of $\mathrm{Ba}$ in the examined granite (av. $=37 \mathrm{ppm})$ suggests generation from crustly dominated magma (Pearce et al. 1984) or could result from liquids affected by a greater extent of biotite fractionation (Dallagnol et al.1999).

On the $\mathrm{Rb}$ versus $(\mathrm{Y}+\mathrm{Nb}$ ) diagram (Fig.20) of Pearce et al. (1984) all samples are plotted in the field of within - plate granite (WPG).

On the $\mathrm{Rb}$ versus $\mathrm{Sr}$ variation diagram of Condie (1973) we can deduce that the studied samples evolved from magma at a crustal thickness more than $30 \mathrm{~km}$ (Fig.21).

On the normative $\mathrm{Qz}-\mathrm{Ab}$ - Or ternary diagram of Tuttle and Bowen (1958), the temperature isotherms indicate temperature of crystallization between $670^{\circ}$ and $800^{\circ} \mathrm{C}$ (Figs.22\&23) and the pressure isobars indicate formation under pressure varying between 0.5 


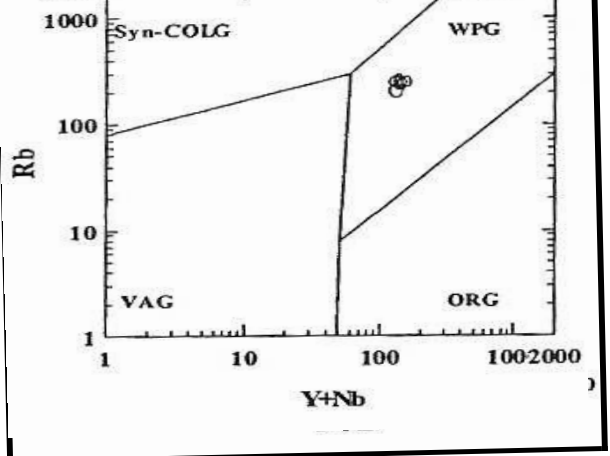

Fig.20: Rb vs. (Y+Nb) diagram, According to Pearce et al. (1984)

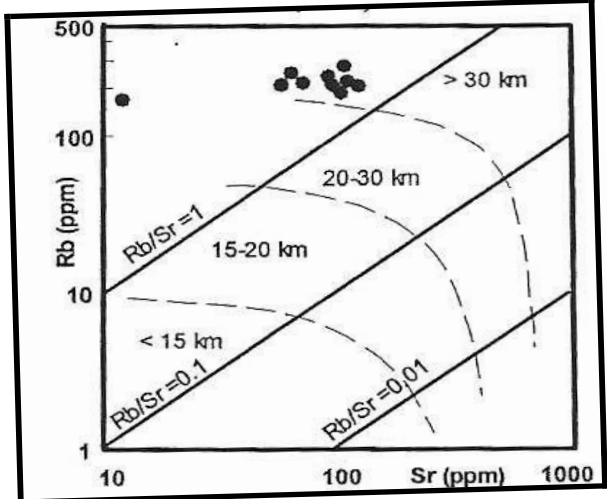

Fig. 21: Rb vs. Sr diagram (According to Condie, 1973).

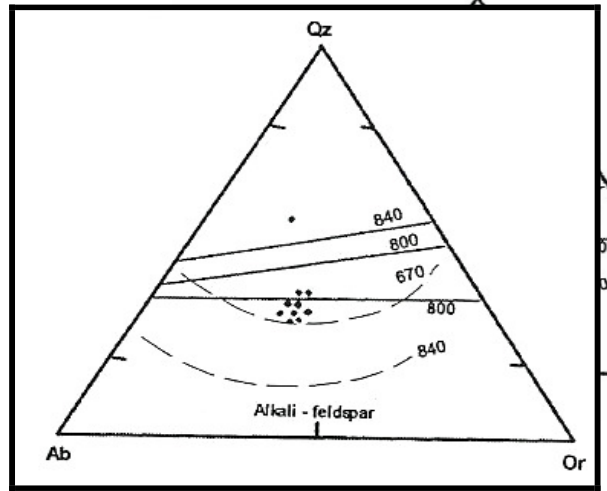

Fig.22: Normative Qz-Ab-Or diagram. According to Tuttle and Bowen(1958),

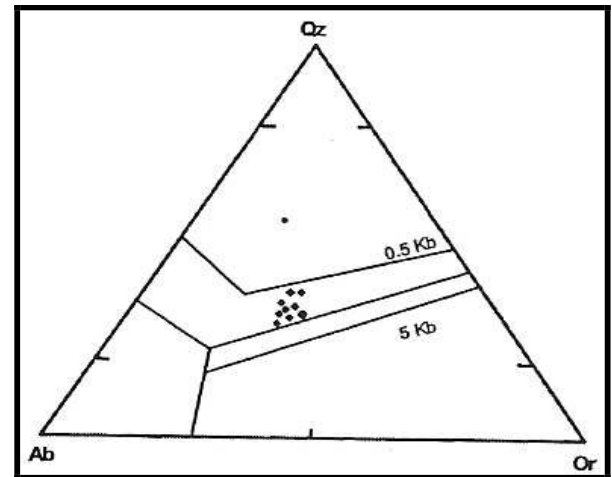

Fig.23: Normative QZ-Ab-Or diagram. According to Tuttle and Bowen(1958), at $\mathrm{P}_{\mathrm{H} 2 \mathrm{O}}=0.5 \mathrm{~K} \mathrm{~b}$

and $3.0 \mathrm{~kb}$ for the studied younger granite, except one sample (sample no. 5).

The binary diagrams (Fig. 24) show positive relations between $\mathrm{Sr}-\mathrm{K}_{2} \mathrm{O}$ and $\mathrm{Sr}-\mathrm{CaO}$ but a negative relation between $\mathrm{Zr} \& \mathrm{Rb}$ (Fig.25).

\section{PETROGENESIS}

Systematic trace element discrimination diagrams (Whalen et al., 1987; also Pearce et al. 1984), which encompass granites from almost all possible tectonic settings have indicated that they can, on the basis of $\mathrm{Nb}, \mathrm{Y}, \mathrm{Ta}$, $\mathrm{Yb}$ and $\mathrm{Rb}$ trace element data, discriminate between volcanic-arc, ocean ridge, within-plate and collisional (syn- and post-collisional) type granites.

The post-orogenic granitoids seem to have been emplaced shortly and rapidly after plate collision. The time span between the transitions from the late orogenic to the post-orogenic magmatism in the Egyptian Shield is taken to be about 6 to 15 m.y. (Beyth eta/., 1994). Thus, the transition from compressional to extensional tectonic environments is directly expressed in the changing composition of the granitic magma.

The geochemical data exhibit a wide range of $\mathrm{K} / \mathrm{Rb}$ ratios $(151-170)$. These values are 

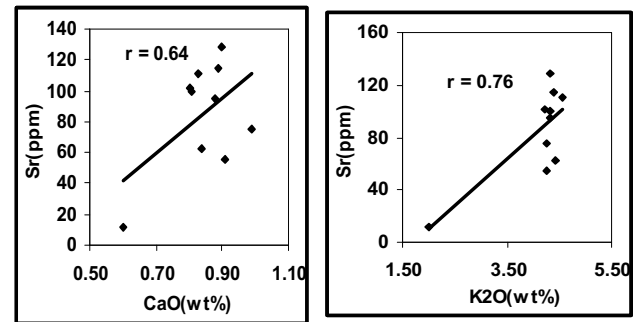

Fig. 24: Variation diagram of $\mathrm{Sr}-\mathrm{Ca} \& \mathrm{Sr}-\mathrm{CaO}$

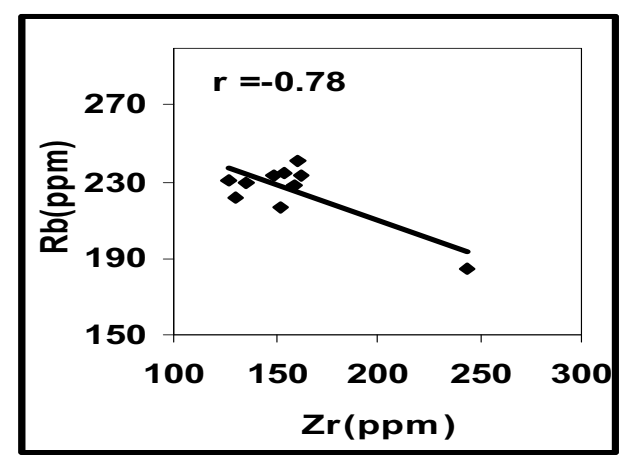

Fig. 25: Variation diagram of $\mathrm{Zr}-\mathrm{Rb}$.

lower than the average crustal value of 285 (Taylor and Mcleman 1985). There is also significant variation in the $\mathrm{Ba} / \mathrm{Rb}$ ratios $(0.13$ 0.21 ) which displays a slight enrichment of $\mathrm{Rb}$ relative to $\mathrm{Ba}$ in the source magma. This suggests the important role of crustal fractionation in the evolution of the studied granite. The ratio of $\mathrm{Rb} / \mathrm{Sr}$ in the studied samples (1.79-15.42) is higher than 1.5 , due to the pre-existing material in the source region as suggested by Bucanan, 1982

\section{GRANITE DIFFERENTIATION}

The chemical analysis reveals that the studied younger granites are characterized by high silica content, with respect to alumina, impoverished in calcium as well as the ferromagnesian elements $\left(\mathrm{Fe}_{2} \mathrm{O}_{3}+\mathrm{MgO}\right)$ and is enriched in alkali elements $\left(\mathrm{Na}_{2} \mathrm{O}+\mathrm{K}_{2} \mathrm{O}\right)$. It is clear that the contents of trace elements in the studied granite is characterized by high $\mathrm{Rb}$ content with depletion in $\mathrm{Sr}$ content, similar to the red-pink granite of El-Missikat granite as mentioned by Bakhit et al. (1999).
Greenberg (1981) mentioned that the younger granites apparently were formed at time when North Africa was being converted from an area of compressive tectonics and crustal instability to an area of stable continental craton. The younger granite magmas appear to have been derived by very limited partial fusion rather than as end products of differentiation of calc-alkaline magma series. $\mathrm{He}$ also stated that the younger granites are generally siliceous $\left(65 \%-77 \%, \mathrm{SiO}_{2}\right)$ and rich in alkalis $\left(7.8-9.3 \%, \mathrm{Na}_{2} \mathrm{O}+\mathrm{K}_{2} \mathrm{O}\right)$. He classified the Egyptian granites into three groups. Plutons near the SiO2- rich end point are classified as "group I". Those near the mafic end product $\left(65-70 \% . \mathrm{SiO}_{2}\right)$ are classified as "group III". Intermediate plutons are classified as "group II". In general, Group I and Group II are rich in $\mathrm{K}$-feldspar and have $\mathrm{K}_{2} \mathrm{O}$ in excess of $\mathrm{Na}_{2} \mathrm{O}$, while Group III are more sodic .Typical group III averages are 3.64\% $\mathrm{K}_{2} \mathrm{O}$ and $4.57 \% \mathrm{Na}_{2} \mathrm{O}$ while those of group I are $4.71 \% \mathrm{~K}_{2} \mathrm{O}$ and $4.04 \% \mathrm{Na}_{2} \mathrm{O}$. Accordingly, the examined granite plutons are equivalent to group II of Greenberg (1981) as shown in Table (2). These results coincides with the data obtained by Bakhit (1999) on the fertile granite of Gabal El-Missikat, Gabal El-Erediya and Gabal Kab Amiri areas

\section{RADIOACTIVITY}

The natural radioactivity of rocks stems mainly from their contents of $\mathrm{U}$, Th and $\mathrm{K}^{40}$. Generally, during magmatic differentiation $\mathrm{U}$ and Th increase from basaltic to low Ca-granitic rocks, but the $\mathrm{Th} / \mathrm{U}$ ratio remains constant. Cambon (1994) stated that U content of the different rock types is variable. The postorogenic granitic rocks are the most enriched rocks with U. Maurice (1982) considered that uranium content more than $8 \mathrm{ppm}$ is uraniferous granite. Table (2) shows some granite samples possess U-content more than ppm in turn can be considered as uraniferous granites..

Systematic measurements of gamma radioactivity were carried out to evaluate the 
Table 3: Radioelement concentration in the different rocks of Gabal Al-Aglab area, Central Eastern Desert, Egypt

\begin{tabular}{|c|c|c|c|c|c|c|c|c|}
\hline \multirow{2}{*}{ Rock type } & \multicolumn{2}{|c|}{$\begin{array}{r}\text { Total count } \\
\text { (cps) }\end{array}$} & \multicolumn{2}{|c|}{$\mathrm{eU}(\mathrm{ppm})$} & \multicolumn{2}{|c|}{ eTh (ppm) } & \multicolumn{2}{|r|}{$\mathrm{Th} / \mathrm{U}$} \\
\hline & Av. & Range & Av. & Range & Av. & Range & Av. & Range \\
\hline $\begin{array}{l}\text { Hammamat } \\
\text { and Dokhan } \\
\text { rocks }\end{array}$ & 25 & $20-30$ & 0.5 & $0.3-0.7$ & 2 & $1-3$ & 4 & $3.3-4.3$ \\
\hline $\begin{array}{l}* * \text { Younger } \\
\text { granite }\end{array}$ & 255 & $220-280$ & 7.1 & $3-12$ & 19.9 & $11-35$ & 2.8 & $5.5-2.9$ \\
\hline
\end{tabular}

concentration of uranium and thorium of the younger granite of Gabal Al-Aglab as well as the shear zone using the portable gamma ray spectrometer (UG-130). The latter displays the count rate in counts per second (cps) by calibration; all the measurements were converted into unit of radioelement content $(\mu \mathrm{R} / \mathrm{h})$. The collected data are expressed in counts (Table $3)$. The radioactivity of the Hammamat and Dokhan rocks vary between 20-30 cps (average value $25 \mathrm{cps}$ ). The radioactivity of the younger granite is the highest in the area and varies between 220-280 cps (average 255 cps).

In the present study, the total count can be divided into two distinct levels of radioactivity coinciding with the different type of rocks. These levels are described as follows:

1 - Low radioactivity level $(<12 \mu \mathrm{R} / \mathrm{h})$. These levels represent the lowest radioactivity in the study area. It extends over mainly the periphery and southern part of the area. This level is represented by the oldest rock units (ophiolitic mélange).

2- High radioactivity level $(12-23 \mu \mathrm{R} / \mathrm{h})$. It represents promising target area and covers the central part of the area (Gabal Al-Aglab younger granites) as well as the separated granitic outcrops all over the mapped area.

When analyzing the total count of the aeroradiometric contour map (Aero Service 1984) over the rock units we see excellent coincidence of radiometric boundaries with the lithology. Table (3) shows the eU and eTh contents for the analyzed samples. From this table, the ophiolitic mélange show eU contents rang- ing from 0.6 to $0.7 \mathrm{ppm}$ and eTh from 1 to 3 ppm, while the younger granite shows eU contents from 3 to $10 \mathrm{ppm}$ and eTh from 11 to $35 \mathrm{ppm}$. Normally, thorium is three times enriched than uranium in the granitic rocks (Rogers and Adams, 1969). Any disturbance in this ratio suggests leaching or addition of uranium post magmatic without valuable change in the Th contents, because Th is relatively stable. The studied younger granite shows an average $\mathrm{Th} / \mathrm{U}$ equal to 2.85 . These data indicate homogeneity in the distribution of both $U$ and The. The magmatic processes played the main role in the uranium-thorium distribution of these granites.

\section{Radio-Element Relationships}

$\mathrm{U}, \mathrm{Th}$, and $\mathrm{Nb}$ behave incompatibly in the granitic melt so that, where uranium concentration is controlled by magmatic processes, these elements would be expected to increase (Cuney, 1984). The relation between $U$ and $T h$ may indicate the enrichment or depletion of $\mathrm{U}$ because $\mathrm{Th}$ is chemically stable. Normally, thorium is three times more than uranium in all rock types (Darnelly, 1982). When this ratio is disturbed, it indicates either depletion or enrichment of uranium. The granites of the studied area show positive correlation between U-Th on the binary diagram (Fig. 26) as well as positive relations between $\mathrm{U}, \mathrm{Th}, \mathrm{Nb}$ and $\mathrm{Zr}$ (Table 2). These relationships indicate that uranium in the study area was mainly con-

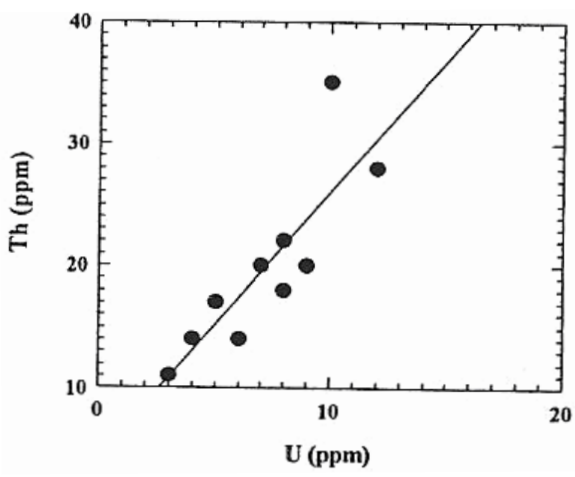

Fig26: U-Th variation diagram 
trolled by primary magmatic processes. The concept is supported by the strong negative correlation between uranium and $\mathrm{Th} / \mathrm{U}$ (Fig. 27). Figures (13-15\&28) show strong relationship between $\mathrm{U}-\mathrm{Zr}$ and $\mathrm{U}-\mathrm{P}_{2} \mathrm{O}_{5}$. This indicates that the $U$ of Gabal Al-Aglab granites were mainly trapped in its accessory minerals such as zircon, sphene and apatite.

\section{URANIUM MINERALIZATION}

The petrographic and mineralogic studies revealed that, the pegmatites at the periphery of the younger granites contain uranium mineralization represented by yellowish secondary uranium- mineral associated with iron oxides. Pure grain of the uranium mineral was hand picked. X ray diffraction (XRD) and scanning electron microscopy (SEM) (Fig.29 \& 30) confirm that it is uranophane $\left[\mathrm{CaO}\left(\mathrm{UO}_{3}\right)_{2}(\mathrm{~S}\right.$ $\left.\left.\mathrm{iO}_{2}\right)_{2}(\mathrm{OH})_{2}, 5 \mathrm{H}_{2} \mathrm{O}\right]$. Table (4) shows the x-ray diffraction data of uranophane AlAglab

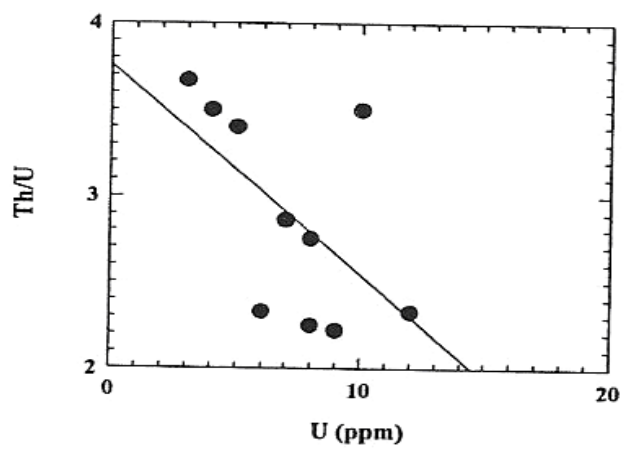

Fig. 27: U-Th/U variation diagram

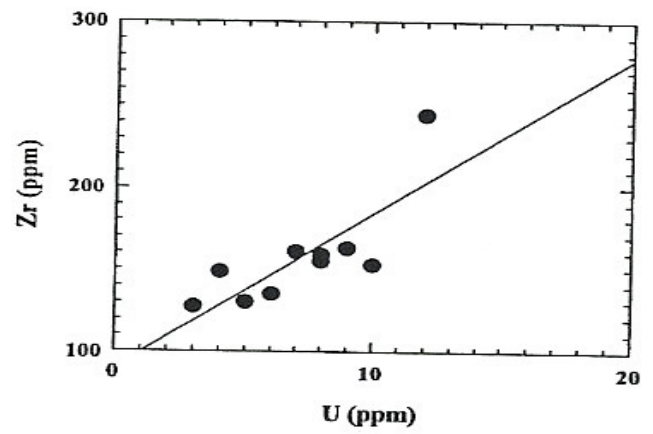

Fig.28: U-Zr variation diagram

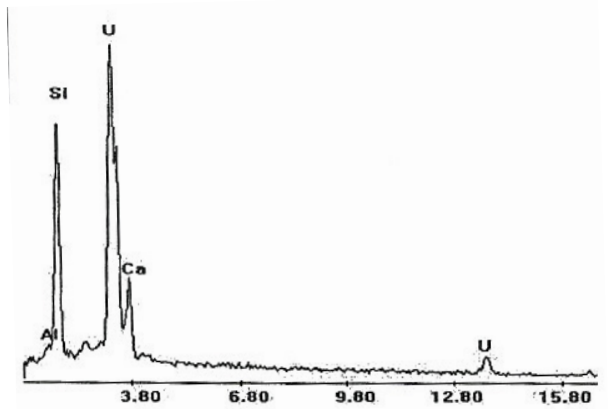

Fig.29: SEM spectrum of Uranophane showing the chemical composition

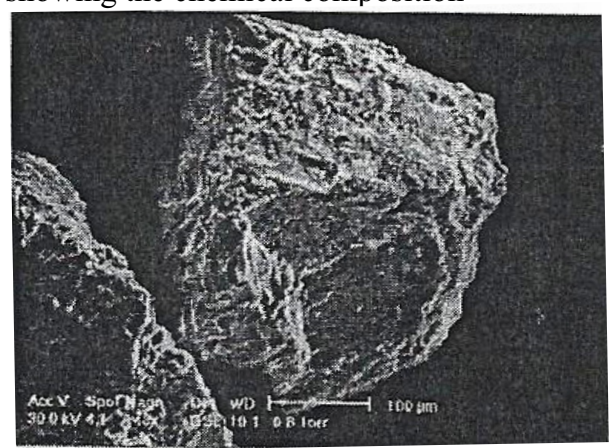

Fig.30: Surface radial structure of Uranophane by using AEM

Table 4: XRD data of Uranophane mineral of Gabal Al-Aglab pegmatites

\begin{tabular}{|c|c|}
\hline \multicolumn{2}{|c|}{ Sp.(51) } \\
\hline $\mathbf{d A}$ & $\mathbf{I} / \mathbf{I}$ \\
\hline 7.90 & 43 \\
\hline 6.61 & 13 \\
\hline 3.97 & 26 \\
\hline 3.51 & 13 \\
\hline 3.20 & 18 \\
\hline 3.00 & 17 \\
\hline 2.91 & 12 \\
\hline \multicolumn{2}{|c|}{ Sp.(55) } \\
\hline dA & $\mathbf{I} / \mathbf{I}$ \\
\hline 7.80 & 45 \\
\hline 6.60 & 15 \\
\hline 3.95 & 30 \\
\hline 3.51 & 15 \\
\hline 3.20 & 21 \\
\hline 2.99 & 18 \\
\hline 2.91 & 13 \\
\hline \multicolumn{2}{|c|}{ Uranophane (8-442) } \\
\hline $\mathbf{d A}$ & I/I \\
\hline 7.88 & 100 \\
\hline 6.61 & 40 \\
\hline 3.97 & 90 \\
\hline 3.51 & 40 \\
\hline 3.20 & 50 \\
\hline 2.99 & 80 \\
\hline 2.91 & 80 \\
\hline
\end{tabular}


Microscopically, uranophane occurs as minute needle-like crystals, fan shaped. It varies from greenish yellow to orange yellow in color with second order interference color and straight extinction. It is always associated with clay minerals and iron oxides. Sometimes, it is seen coating iron oxides and kaolinite due to the ability of iron and clay minerals to adsorb uranium.

\section{CONCLUSIONS}

The field, petrography, geochemistry and radiometric studies of Al-Aglab younger granite denote the following conclusions:

1- Gabal Al Aglab younger granite is classified according to the petrographic and geochemical studies as subsolvus alkali granite. It is holocrystalline, medium to coarse - grained and characterized by the predomenance of perthite over plagioclase, quartz and biotite. Zircon, apatite, titanite, allanite and opaque minerals are the accessory and secondary minerals.

2- It is shows peraluminous to metaluminous character and originated from subalkaline magma in within plate tectonic setting (crustal thickness $>30 \mathrm{~km}$ ) water vapour pressure varies from 0.5 to $3 \mathrm{~kb}$ with crystallization temperature from $670^{\circ}$ to $800^{\circ} \mathrm{C}$.

3- Al- Aglab younger granite is considered as uraniferous granite, where $\mathrm{eU}$ content ranges from 2-10 ppm and eTh from 11-35 ppm with average $\mathrm{Th} / \mathrm{U}$ equal to 2.85 .

4- No uranium mineralization was recorded, but uranium is mainly concentrated in the accessory minerals (as zircon, apatite, sphene and allanite) indicating that $U$ is trapped in accessories.

5- The uranium anomalies are confined to the pegmatite at peripheral zones of the granite intrusion. These marginal uranium anomalies may be related to leaching from the granite by meteoric water

\section{REFERENCES}

Abdel Monem, A.; Bakhit, F., and Ali, M. M.,1990. Trace and rare earth elements geochemistry of the uranium mineralization at El-Erediya, Central Eastern Desert, Egypt. Egypt. Mineral., 2, 143-150.

Areo Service,1984. Final operational report of airline magnetic / radiation survey in the Eastern Desert, Egypt. Egypt. General Petrol. Corpor.,Aero Service, Houton, Texas, six volumes.

Bakhit, F.S.,1978. Geology and radioactive mineralization of Gabal El-Missikat area, Eastern Desert of Egypt, A.R.E. Ph.D. Thesis, Fac. Sci., Ain Shams Univ., Cairo, Egypt, 289 p.

Bakhit, F.S., and El-Kassas, I.A.,1989. Distribution and orientation of radioactive veins in ElErediya and El-Missikat, Central Eastern Desert, Egypt. Int. Remote Sensing, Pristol Univ., 10. no.3, 565-581.

Bakhit, F.S., and Meleik, M.L.,1990. Application of autocorrelation function to structural lineaments in radioactive sample area in the Central Eastern Desert of Egypt. Int. G. Remote Sensing, 11, No. 10, 1919.

Bakhit, F.S., and El-Kassas, I.A.,1992. Distribution and statistical analysis of radioactivity of the basement rocks in Wadi Attalah- El-Missikat area, and correlation with the surrounding areas, Central Eastern Desert Egypt. Ann. Geol. Surv. Egypt, 18, 393-407.

Bakhit, F.S.; Hussein, H.A., and Ali, M.M.,1999. Geotectonics and characteristic features of fertile and non-fertile younger granites, Eastern Desert, Egypt.In: Basement tectonics (Sinha, A.K. ,Ed.): 13,1-24.

Beyth, M.; Stern, R.J.; Altherr, R., and Kroner, A .,1994. The late Precambrian Timna igneous complex, Southern Israel: evidence for comagmatic-type sanukitoid monzodiorite and alkali granite magma. Lithos, 31,103-124.

Bucanan, M. S.,1982. The geochemistry of some igneous rock series. Geochim. \& Cosmochim. Acta, 9,101- 137. 
Cambon, A. R., 1994. Uranium deposits in granitic rocks. Notes on the national training course on uranium geology and exploration. Organized by IAEA and NMA.

Cuney, M.,1978. Geologic environment, mineralogy and fluid inclusions of Bois Noir-Limouzatb uranium vein, Froez, France. Econ. Geol., 73, 1567-1610.

Cuney, M.,1984. Les methods des prospection de l'uranium, Nuclear Energy Agency of the OECD, Paris., 277-292.

Condie, K. C., 1973. Archean magmatism and crustal thickening. Geol. Soc. Amer. Bull., 84, $2981-2991$.

Darnley, A.G.,1982. Hot granites Some general remarks, In: Uranium in granites (Maurice, Y.J. ,Ed.): Geol. Surv. Canada, paper No. 81$23,1-10$.

Dallagnoll, R.; Ramo, O.T.; Magalhaes, M.S., and Macambira, M.J.B., 1999. Petrology of anorogenic oxidized Jamon and Mousa granite. Lithos, 46, 431-462.

El Amin, H., and Alfy, A.,1990. The ophiolitic mélange, south of Gabal Al Aglab Eastern Desert; A petrological and structural approach. Asw Sc Tech. Bull.,II, 117-163.

El-Ramly, M.F.,1972. A new geological map for the basement rocks in the Eastern and South western Desert of Eygpt. Scale v1:1,000,000. Ann. Geol. Surv. Egypt, 2, 1-18.

El-Shazly, EM.; Bakhit, F.S., and Mostafa, M.E.,1981. Significant structure trends and the relation to radioactivity in El-Missikat granite pluton, Central Eastern Desert, Egypt . Ptoc, 6th Int. Cong.for statistics. Comp. Science, Social and Demogr. Research, Ain Shams Univ., Cairo, 399-418.

El-Tahir, M.A.,1985. Radioactivity and mineralization of granitic rocks of El-Erediya occurrence, Eastern Desert, Egypt. Ph. D. Thesis, El-Azhar Univ., Cairo, 224-232.

Greenberg, J.K.,1981. Characteristics and origin of Egyptian younger granite. Geol. Soc. America Bull., part 1,92, 224-256.

Hassan, M. A., and Hashad, A.H., 1990. Precambrian of Egypt. In: The geology of Egypt (Said R.,Ed): Balkema, Rotterdam,201-245.

Hussein, H. A.; Hassan, M. A.; El-Tahir, M.A., and Abu Dief, M. A.,1986. Uranium bearing siliceous veins in younger granites, Eastern Desert, Egypt, Int. Atomic Energy Agency Report, no. $361,143-157$.

Hussein, A.M., and Sayyah, T.A.,1991. Uranium of the younger granites of Egypt. Inter. Atomic Energy. Vienna, Austria, 14 p.

Kroner, A.,1993. Thrust tectonics in the Pan-African basement of SE Egypt. CIFEG Puble. Oce.3.

Lehmann, B.,1982. Metallogeny of tin magmatic differentiation versus geochemical heritage. Economic geology, 77, 50-69.

Maniar, P. D., and Piccoli, P. M.,1989. Tectonic discrimination of granitoids. Geol. Soc. Am. Bull., 101, 635-643.

Mason, B., and Moore, C.B.,1982. Principles of geochemistry. 4th ed. John Wiley, New York, $530 \mathrm{p}$.

Mason, B. ,1966. Principles of geochemistry 3rd Ed. John Wiley, New York, 10.

Maurice, P.,1982. The Mineralogy and Geochemistry of uranium, thorium and rare earth elements in two radioavtive granites of the Vosoges, France, Minnd. , 46, 149-161.

Middlemost, E.A.M.,1985. Magma and magmatic rocks: An introduction to igneous petrology. Longman Inc., New York,651p.

Moghazi, A.M.; Andersen, T.; Oweiss, G.A., and Elbouseily, A.M.,1998. Geochemical and Sr$\mathrm{Nd}-\mathrm{Pb}$ isotopic data bearing on the origin of Pan-African granitoids in the Kid area, southeast Sinai, Egypt. J. Geol. Soc. Lond., 155,697710. 
Moharem, A. F.,1997. Geological and geochemical studies on the uranium bearing granites in the northern part of Gabal Gattar, North Eastern Desert .M. Sc. Thesis, Ain Shams Univ., 145p.

Moharem, A. F.,1999. Geology, geochemistry and radioactivity of the area of Gabal ElMaghrabiya, central Eastern Desert, Egypt. Ph.D. Thesis, Fac. Sci., Ain Shams Univ., Cairo, Egypt, 211 p.

Pearce, J.A.; Harris, N.B.W., and Tindle, A.G.,1984. Trace element discrimination Diagrams for the tectonic interpretation of granitic rocks. J. petrol.,25,956- 983

Rashid, A.A.,1998. Petrogenesis of the Late Proterozoic fractionated granite of Gabal Mudargag El Ahmar, central Eastern Desert, Egypt. Egypt. Mineral.,10,104-119.

Rogers, J. J. W. , and Adams, J. S. S.,1969. Uranium. In: Handbook of geochemistry (Wedepohl, K. H.,Ed.): New York, Springer - Verlag, 4, $92 \mathrm{~B} 1$ to $92 \mathrm{C} 10$

Roz, M.E.,1994. Geology and uranium mineralization of Gabal Gattar area, north Eastern Desert, Egypt. M.Sc. Thesis, Fac. Sci, Al Azhar Univ., Cairo, Egypt. 175p

Schandelmeier, H.; Richter, A., and Harms, U.,1987. Proterozoic deformation of the East Saharan Craton in outheast Libya, south Egypt and north Sudan. Tectonophysics,140,233246.
Shalaby, M. H.,1995. New occurrence of uranium mineralization G VII, Gabal Qattar uranium prospect, north Eastern Desert, Egypt. Bull. Fac. Sci. Alex. Univ., 35, No.2,447-460.

Stern, R. J.,1993. Tectonic evolution of the Late Proterozoic East African Orogen; constraints from crustal evolution in the Arabian Nubian Shield and the Mozambique Belt. In: Thorweihe,7374.

Stern, R. J., and Hedge, C. E., 1985. Geochronologic and isotopic constraints on late Precambrian crustal evolution in the Eastern Desert of Egypt. Am. J. Sci., 258, 97-127.

Stoeser, D.B., and camp, V.E.,1985. Pan African microplate accretion of the Arabian Shield. Geol. Society Amer. Bull., 96, 817-826.

Streckeisen, A.,1976. To each plutonic rock its proper name. Earth Sci. Rev., 12,1 - 33.

Tuttle, O. F., and Bowen, N. L., 1958. Origin of granite in the light of experimental studies in the system Na A1 Si3O8 - SiO2 - H2O. eol. Soc. Amer. Mem., 74, 153 p.

Taylor, S.R., and Mclennen, S. M.,1985. The continental crust; its composition and evolution, Blackwell, Oxford ,235p.

Whalen, J. B.; Currie, K. L., and Chappel, B. W. ,1987. A-type granites: Geochemical characteristics, discrimination and petrogenesis. Contrib. Mineral. Petrol.,95, 407-419. 


\section{بترولوجية و إثعاعية الجرانيت الحديث لجبل الأجلب ، وسط الصحراء الثرقية ، مصر}

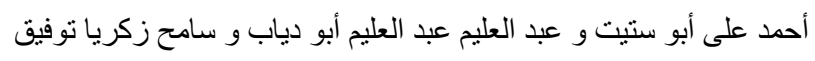

يهدف البحث إلى دراسة بترولوجية و إثتعاعية صخور منطقة جبل الأجلب بالصحر اء الثرقية. و قد أمكن

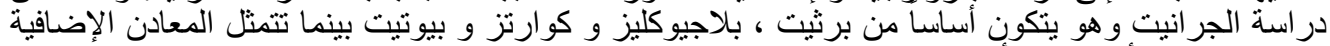

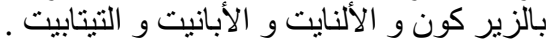

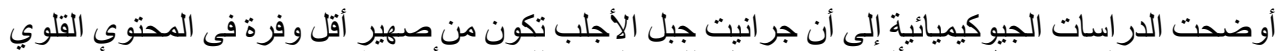

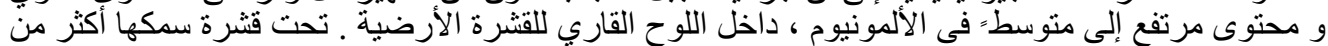

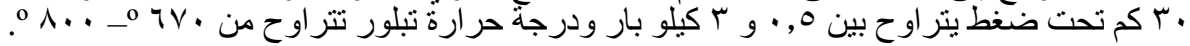

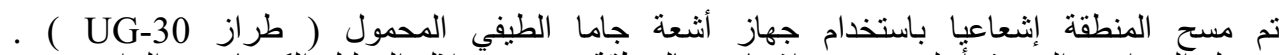

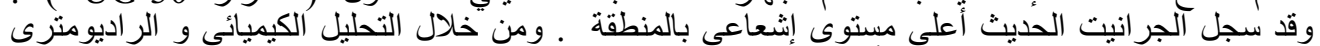

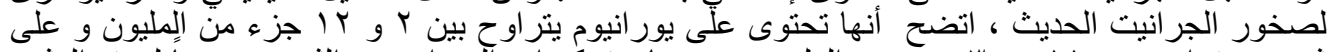

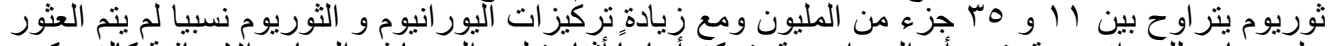

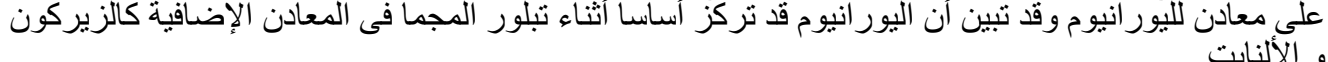

